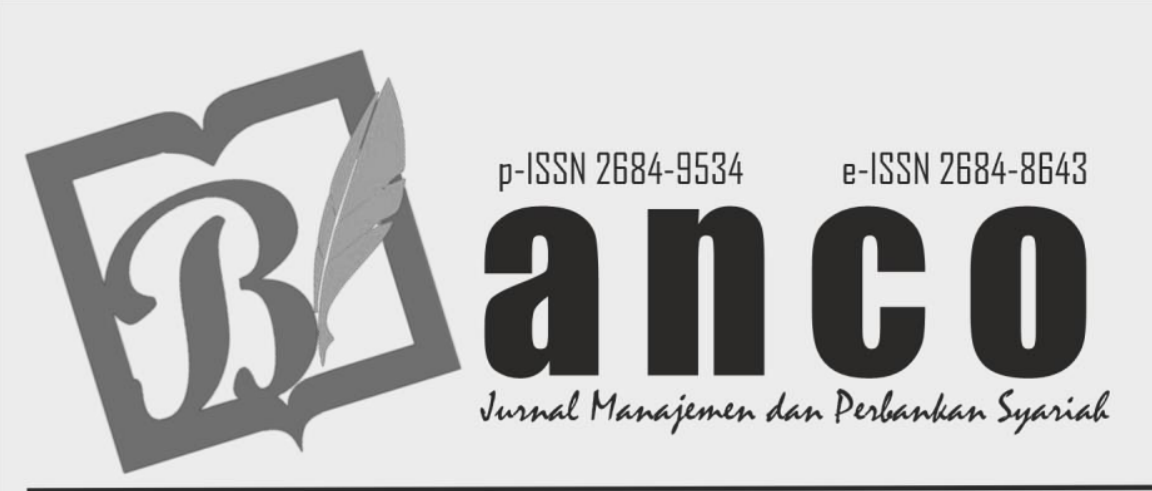

https://ejurnal.iainpare.ac.id/index.php/banco/index

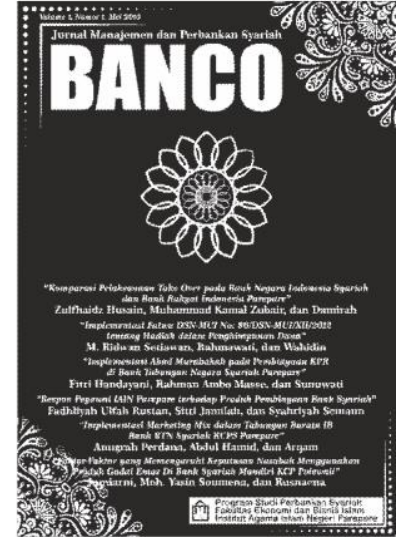

\title{
PENGARUH QUALITY OF WORK LIFE (QWL) TERHADAP KINERJA PEGAWAI DI BANK DANAMON SYARIAH MAKASSAR
}

\author{
Syarif Al Qadri \\ IAIN Parepare \\ syarifqadri@iainpare.ac.id
}

Moh. Yasin Soumena

IAIN Parapare

yasinsoumena@iainpare.ac.id

Muhammad Kamal Zubari

IAIN Parepare

kamalzubair@iainpare.ac.id

\begin{abstract}
This study discusses the influence of Quality of Work Life conducted by Bank Danamon Syariah Makassar. Quality of Work Life is a management concern about how work can affect humans, organizational effectiveness and the importance of employee participation in decision making processes, especially those related to career, income and time. front of them in their work. The purpose of this research is to find out whether the effect of Quality of Work Life consisting of Rewards System, Work Environment, and Work Restructuring variables influences employee performance. And to find out the dominant variables simultaneously influencing.

This research is a quantitative research with descriptive method. The data collection is done through the distribution of questionnaires. The method used to test hypotheses is to use Validity Test, Reliability Test, Normality Test, Multiple Regression Analysis, T Test, F Test, Adjusted R Square, and Double R Correlation.

Linear regression test results, $\mathrm{Y}=11,976+0.488 \times 1+0.081 \times 2+0.033 \times 3$, it can be concluded that the variable $\mathrm{X} 1$ is the Rewards System that has a value of 0.488 and has a positive and significant effect on employee performance variables (Y), variable X2, namely Environment Work with a value of 0.081 does not have a positive and significant effect on the Employee Performance variable (Y), variable X3, namely Work Restructuring, which has a value of 0.033 , does not have a positive and significant effect on the employee
\end{abstract}




\section{Syarif Al Qadri, Moh. Yasin Soumena}

performance variable $(\mathrm{Y})$. The results of this study indicate: based on the $\mathrm{t}$ (partial) calculation of the reward system, the calculated value is 3.450 and the value (sig) $=0.002$ is smaller than the probability value that is 0.05 or $0.002<0.05$, meaning that the dominant reward system variable has a positive and significant effect on employee performance at Bank Danamon Syariah Makassar. T-test results (partial) work environment obtained a calculated value of 0.650 and (sig) $=0.521$ greater than the probability that is, 0.05 or $0.521>0.05$ means that the work environment variable does not affect the performance of employees at Bank Danamon Syariah Makassar. And the t-test results (partial) work restructuring obtained a calculated value of 0.239 and (sig) = 0.813 greater than the probability of 0.05 or $0.813>0.05$ which means the work restructuring variable has no effect on employee performance at Bank Danamon Syariah Makassar.

Keywords: Reward System, Work Environment, Reconstruction, dan Performance

\section{Abstrak}

Penelitian ini membahas tentang pengaruh Quality OfWork Life yang dilakukan oleh Bank Danamon Syariah Makassar.Quality of Work Life merupakan kepedulian manajemen tentang bagaimana pekerjaan dapat mempengaruhi manusia, efektifitas organisasi dan pentingnya partisipasi pegawai dalam proses pengambilan keputusan terutama yang berhubungan dengan karir, penghasilan dan masa depan mereka dalam pekerjaannya. Adapun penelitian ini yang bertujuan untuk mengetahui apakah Pengaruh Quality OfWork Life yang terdiri dari variabel Sistem Imbalan, Lingkungan Kerja, dan Restrukturisasi Kerja berpengaruh terhadap kinerja pegawai. Serta untuk mengetahui variabel yang dominan berpengaruh secara simultan.

Penelitian ini merupakan penelitian kuantitatif dengan metode deskriptif. Adapun pengumpulan data dilakukan melalui penyebaran kuesioner. Metode yang digunakan untuk menguji hipotesis adalah dengan menggunakan Uji Validitas, Uji Reliabilitas, Uji Normalitas, Analisis Regresi Berganda, Uji T, Uji F, Koefisien Determinasi (Adjusted R Square), dan Korelasi Ganda R.

Hasil uji regresi linear, $\mathrm{Y}=11.976+0.488 \times 1+0.081 \times 2+0.033 \times 3$, maka dapat ditarik kesimpulan bahwa variabel X1 yaitu Sistem Imbalan yang bernilai 0,488 berpengaruh positif dan signifikan terhadap variabel kinerja pegawai $(\mathrm{Y})$, variabel X2 yaitu Lingkungan Kerja yang bernilai 0,081 tidak berpengaruh positif dan tidak signifikan terhadap variabel Kinerja Pegawai (Y), variabel X3 yaitu Restrukturisasi Kerja yang bernilai 0,033 tidak berpengaruh positif dan tidak signifikan terhadap variabel kinerja pegawai $(\mathrm{Y})$. Hasil penelitian ini menunjukkan: berdasarkan pada perhitungan $\mathrm{t}$ (parsial) sistem imbalan memperoleh nilai hitung sebesar 3,450 dan nilai $(\mathrm{sig})=0,002$ lebih kecil dari nilai probability yakni 0,05 atau $0,002<0,05$ artinya variabel sistem imbalan dominan berpengaruh positif dan signifikan terhadap kinerja pegawai di Bank Danamon Syariah Makassar. Hasil uji t (parsial) lingkungan kerja memperoleh nilai hitung sebesar 0,650 dan (sig) = 0,521 lebih besar dari probability yakni, 0,05 atau 0,521 >0,05 artinya variabel lingkungan kerja tidak berpengaruh terhadap kinerja pegawai di Bank Danamon Syariah Makassar. Dan hasil uji t (parsial) restrukturisasi kerja memperoleh nilai hitung sebesar $0,239 \mathrm{dan}(\mathrm{sig})=0,813$ lebih besar dari probability yakni 0,05 atau $0,813>0,05$ yang berarti variabel restrukturisasi kerja tidak berpengaruh terhadap kinerja pegawai di Bank Danamon Syariah Makassar.

\section{Kata Kunci: Sistem Imbalan, Lingkungan Kerja, Restrukturisasi Kerja, dan Kinerja}

\section{A. Pendahuluan}

Persaingan dunia usaha dewasa ini tampak semakin meningkat, hal ini menyebabkan manajemen setiap perusahaan mendapat tantangan untuk berusaha secara kompetitif. Perusahaan yang ingin berhasil memperoleh laba serta bertahan bertahun-tahun, tumbuh dan berkembang harus mampu mengelola usahanya dengan menggunakan manajemen yang baik.(Anonim, 2017)

Manajemen sumber daya manusia (SDM) merupakan salah satu faktor untuk untuk meningkatkan dukungan sumber daya manusia dalam mencapai tujuan organisasi melalui peningkatkan produktivitas pegawai, menurunkan perputaran kerja dan mengurangi tingkat absensi sekaligus meningkatkan kepuasan kerja pegawai 
dan juga pengembangan sumber daya manusia. (Muhammad Idris. D.M, 2018) Semua perusahaan pasti membutuhkan SDM atau sumber daya manusia yang handal dan siap bersaing dengan perusahaan lainnya. Perbankan pun tidak akan lepas dari adanya SDM yang benar-benar tangguh dan siap kerja. Sumber daya manusia adalah pengerak usaha bagi bank, jika tidak ada sumber daya manusia, pastinya bank tidak akan bisa beroperasional. Bank tidak segan-segan untuk melakukan berbagai macam tindakan untuk mendapatkan SDM yang benar-benar sesuai dengan kebutuhan bank saat ini. Pada dasarnya kinerja karyawan merupakan hasil proses yang kompleks, baik berasal dari diri pribadi karyawan (internal factor) mau pun upaya strategis dari perusahaan. Faktor-faktor internal yang mempengaruhi kinerja misalnya motivasi, tujuan, harapan dan lain-lain, sementara contoh faktor eksternal yang mempengaruhi kinerja adalah lingkungan fisik dan nonfisik perusahaan. Kinerja yang baik tentu saja merupakan harapan bagi semua perusahaan dan institusi yang mempekerjakan karyawan, sebab kinerja karyawan ini pada akhirnya diharapkan dapat meningkatkan kinerja perusahaan secara keseluruhan. (Murtiyani, 2016)

PT Bank Danamon Syariah adalah salah satu perusahaan yang bergerak di bidang jasa, salah satu tugasnya adalah melayani masyarakat umum yang ingin melakukan transaksi menabung serta pembiayaan di kantor PT Bank Syariah Danamon. Dalam hal melayani masyarakat umum, setiap karyawan dituntut untuk selalu ramah kepada setiap pengunjung yang datang ke bank tersebut. (Finthariasari et al., 2020)

Namun yang perlu mendapat perhatian dari pimpinan yang penting adalah keadaan lingkungan kerja di dalam organisasi (internal) dan eksternal. Berbagai masalah internal misalnya rasa bosan atau jenuh yang melanda karyawan. Pimpinan organisasi berusaha menemukan cara mengatasi kebosanan karyawan yang disebabkan oleh ketidakpuasan kerja tersebut, terutama menyangkut masalah kemerosotan mutu kehidupan kerja. (Mega Yunika, 2017)

Pengelolaan dan penyediaan sarana dan prasarana dalam rangka mewujudkan lingkungan kerja dan iklim kerja yang kodusif diharapkan bisa mendorong pegawai untuk selalu berinovasi dan berkreasi termasuk membuat sistem yang fair dan struktur yang fleksibel dengan pembagian tugas, wewenang dan tanggung jawab yang jelas dan manusiawi dengan memperhatikan kemampuan pegawai dan usahanya dalam mencapai tujuan karimya. Organisasi perlu mengerti dan memahami apa yang menjadi motivasi dan kebutuhan para pegawai dalam lingkungan kerjanya. Salah satu konsep untuk mengembangkan sebuah lingkungan organisasi yang baik untuk pegawai adalah konsep Quality of Work Life (QWL). Konsep ini mengemukakan pentingnya penghargaan terhadap manusia dalam lingkungan kerjanya. (Fadilla Helmi \& Elita, 2013)

Quality of Work Life adalah sebuah proses dimana organisasi memberikan respon pada kebutuhan karyawan dengan cara mengembangan mekanisme untuk mengijinkan para karyawan memberikan sumbang saran penuh dan ikut serta mengambil keputusan dan mengatur kehidupan kerja mereka dalam suatu perusahaan. Berbagai faktor perlu dipenuhi dalam menciptakan program QWL, antara lain restrukturisasi kerja, partisipasi kerja,lingkungan kerja dan sistem imbalan. (Soepomo, 2013) Program kualitas kehidupan kerja dimaksudkan agar dilakukan perbaikan terus menerus untuk membangkitkan kinerja karyawan, misalnya dengan memberi kesempatan yang lebih baik dalam berpartisipasi, tantangan, harapan, dan kesejahteraan yang lebih menjanjikan. (Saputro, 2019) Faktor restrukturisasi merupakan salah satu pilar dalam Manajemen Sumber Daya Manusia di perusahaan, yang bertujuan mencari dan mendapatkan sumber sumber daya manusia yang kompeten dibidangnya atau proses menarik orang-orang pada waktu yang tepat, dalam jumlah yang cukup, dan dengan persyaratan yang layak, untuk mengisi lowongan dalam organisasi. (Setiawan, 2021) Dari hasil observasi awal diidentifikasi bahwa factor restrukturisasi kerja ini belum sepenuhnya diterapkan secara optimal di PT.Bank Danamon Syariah Makassar, para karyawan diberi tugas yang monoton, padahal para pekerja yang didominasi para ahli dalam bidang keuangan diyakini sangat berambisi dapat terus mengembangkan keahlian dan karier karyawan. (Rahayu, 2018) 


\section{Syarif Al Qadri, Moh. Yasin Soumena}

Faktor partisipasi berupa keinginan keterlibatan karyawan dalam proses pembuatan berbagai keputusan organisasional secara proporsional, tetapi tidak berarti semua karyawan harus dilibatkan dalam pembuatan semua kebijakan. Faktor lingkungan kerja berupa keadaan fisik dan non fisik yangmemberikan kenyamanan, kesan menyenangkan dan aman bagi karyawan. (Suharyanto et al., 2012) Faktor sistem imbalan diyakini merupakan suatu hal yang sangat penting karena semua pekerja membutuhkan imbalan yang dapat menutup kebutuhan pribadi dan keluarganya, sehingga diduga faktor sistem imbalan ini dominan mempengaruhi kinerja karyawan di PT.Bank Danamon Syariah Makassar. Untuk ini perlu diteliti apakah masalah sistem kinerja ini sudah dikelola dengan baik, adil dan wajar.(Soepomo, 2013)

Perusahaan yang kurang memperhatikan faktor kualitas kehidupan kerja sepertinya akan sulit mendapatkan atau mempertahankan pekerjaan yang sesuai dengan kebutuhan perusahaan, bahkan akan sulit membangkitkan kinerja karyawan yang sudah ada. Dan lebih dari itu akan menghadapi kondisi perpindahan pekerja (labour turnovers) karena karyawan lebih memilih untuk bekerja di tempat atau perusahaan lain yang menerapkan berbagai faktor kualitas kehidupan kerja yang lebih menjanjikan. (Trimaya, 2014)

Kinerja karyawan hanya dapat ditumbuhkan apabila iklim kerja menarik minat pekerja yang dibutuhkan, betah dan bersedia mengerahkan segala kemampuannya dalam bekerja. (Badu Ahmad, 2008)

\section{B. Diskusi dan Pembahasan}

\section{Sejarah Bank Danamon Syariah}

PT Bank Danamon Tbk atau Bank Danamon didirikan pada tahun 1956 dengan nama PT

Bank Kopra Indonesia. Pada tahun 1976 namanya menjuadi Bank Danamon Indonesia, hingga kini Bank Danamon menjadi bank devisa swasta pertama di Indonesia tahun 1976 dan perseroan terbuka pada tahun 1989. Pada tahun 1997, sebagai akibat krisis moneter asia, bank danamon mengalami kesulitan likuiditas dam diambil alih oleh Badan Penyehatan Perbankan Nasional BPPN sebagai bank BTO. Pada tahun 1999, pemerintah Indonesia melalui BPPN. Pada tahun 2000, delapan bank BTO lainnya dilebur ke dalam Bank Danamon. Namun sebagai surviving entity, Bank Danamon bangkit menjadi salah satu pilar perbankan nasional, dalam kurun waktu tiga tahun berikutnya, Bank Danamon melakukan restrukturisasi luas mencakup manajemen, manusia, organisasi, sistem, nilai perilaku serta identitas perusahaan. (Rizki et al., 2019)

Upaya ini berhasil meletakkan fondasi maupun prasarana baru bagi perseroan guna meraih pertumbuhan berdasarkan transparansi, responsibilitas, integritas, profesionalisme TRIP. Pada tahun 2013, Bank Danamon diambil alih oleh Konsorsium Asia Fimamce Imdonesia sebagai pemegang saham pengendali. Dengan kendali manajemen baru, serta modal 180-hari pemetaan modal bisnis dan strategi baru, Bank Danamon terus menjalani perubahan transformasional yang dirancang untuk dijadikannya sebagai bank nasional terkemuka dan pelaku regional unggulan. (Paramarta, 2019) Berdasarkan aspek sejarah berdirinya Bank Danamon Syariah, maka penulis berpendapat bahwa Bank Danamon Syariah merupakan Unit Usaha Syariah UUS Bank Danamon dan bukan Bank Umum Syariah BUS. Jadi, secara structural Bank Danamon Syariah masih dibawah Bank Danamon. (Warpindyastuti, 2020)

\section{Deskripsi Data Responden}

Dalam penelitian ini menguraikan mengenai Quality of Work Life (QWL) sebagai kinerja pegawai pada bank Danamon Syariah Makassar. Hal ini bertujuan untuk mengetahui pengaruh Quality Of Work Life (QWL) terhadap kinerja pegawai Bank Dananon Syariah Makassar. (Irawan \& Ekapradana, 2020) Dalam penelitian ini, diambil sebanyak 30 pegawai sebagai sampel. 
Populasinya adalah nasabah Bank Danamon Syariah Makassar dan metode yang digunakan adalah metode kuesioner atau angket dengan memberikan kuesioner atau angket kepada pegawai khususnya Pegawai Bank Danamon Syariah Makassar. (Putri, 2015)

Karaksteristik responden yaitu menguraikan deskripsi identitas responden menurut sampel penelitian yang telah ditetapkan. Salah satu tujuan dengan deskripsi tersebut ialah memberikan gambaran yang menjadi sampel dalam penelitian ini. Dalam penelitian sampel karakteristik responden dikelompokkan menurut jenis kelamin, umur, pekerjaan. Oleh karena itu, uraian mengenai karakteristik responden dapat diuraikan sebagai berikut:

Tabel 4.1

Sampel Pegawai Bank Danamon Syariah Makassar

\begin{tabular}{|c|c|c|c|c|c|}
\hline NO & NAMA & ALAMAT & $\begin{array}{c}\text { JENIS } \\
\text { KELAMIN }\end{array}$ & PEKERJAAN & USIA \\
\hline 1 & Riski Purnamasari & Jl. Hertasning $27 \mathrm{~B}$ & Perempuan & Karyawan Swasta & 25 \\
\hline 2 & Mirnawati & Jl. Dg Tata 5 No. 26 & Perempuan & Karyawan Swasta & 26 \\
\hline 3 & Ince Abd. Wahid & BTN Minasa Upa & Laki-laki & Karyawan Swasta & 28 \\
\hline 4 & Yunita & Komp Lily Blok F 15 B & Perempuan & Karyawan Swasta & 24 \\
\hline 5 & Nasir P & Jl. Borong Raya 1 Lr 2 & Laki-laki & Karyawan Swasta & 25 \\
\hline 6 & Gabriella Angeli & Jl. Veteran & Perempuan & Karyawan Swasta & 23 \\
\hline 7 & Sheren Geraldine & Jl. Hertasning Raya No. 15 & Perempuan & Karyawan Swasta & 26 \\
\hline 8 & Nur Fajrin & Jl. Ar Dg Unjung Lr 1 & Perempuan & Karyawan Swasta & 25 \\
\hline 9 & Dian Mega Resky & Jl. Boulevard Raya & Perempuan & Karyawan Swasta & 25 \\
\hline 10 & Andi Aliftama & Jl. Pampang Lr 5 Mks & Laki-laki & Karyawan Swasta & 29 \\
\hline 11 & Hervan Saputra & BTP Blok F/15 B & Laki-laki & Karyawan Swasta & 26 \\
\hline 12 & Ardiansyah & Jl. Asrama Haji / Goa Ria & Laki-laki & Karyawan Swasta & 27 \\
\hline 13 & Bayu Ilahude & Jl. Teuku Umar No. 10 & Laki-laki & Karyawan Swasta & 28 \\
\hline 14 & Deni Marvianto & Jl. Tentara Pelajar & Laki-laki & Karyawan Swasta & 25 \\
\hline 15 & Wandi Ryan & Jl. Korban 40.000 Jiwa Mks & Laki-laki & Karyawan Swasta & 30 \\
\hline 16 & Yessy Christianty & Jl. 5 Pareman No. 143 B & Perempuan & Karyawan Swasta & 27 \\
\hline 17 & Ahmad Saldi & Jl. Perintis Kemerdekaan III & Laki-laki & Karyawan Swasta & 26 \\
\hline 18 & Radila Tunjung & Jl. Racing Center No. 14 B & Perempuan & Karyawan Swasta & 23 \\
\hline 19 & Husnul Khatimah & Jl. Abd Dg Sirua No. 15 B & Perempuan & Karyawan Swasta & 25 \\
\hline 20 & Noaim Imran & Jl. Sibala Dalam No. 88 & Laki-laki & Karyawan Swasta & 22 \\
\hline 21 & Anggraeni & Jl. Perintis Kemerdekaan III & Perempuan & Karyawan Swasta & 23 \\
\hline 22 & Divayanti & Jl. Maccini Kidul No. 90 & Perempuan & Karyawan Swasta & 24 \\
\hline 23 & Firmansyah R & Jl. Rappoccini Raya & Laki-laki & Karyawan Swasta & 26 \\
\hline 24 & Kartika Ahmad & Jl. Antang & Perempuan & Karyawan Swasta & 24 \\
\hline 25 & Alfina Fitria S & Jl. Asrama Haji & Perempuan & Karyawan Swasta & 25 \\
\hline 26 & Putri Nur Annisa & Jl. Telkomas Tamalanrea & Perempuan & Karyawan Swasta & 24 \\
\hline 27 & Arfadhia Fakhri & Jl. Veteran Selatan lr II & Laki-laki & Karyawan Swasta & 25 \\
\hline 28 & Mirza Pradipa & Jl. Urip Sumoharjo V & Perempuan & Karyawan Swasta & 26 \\
\hline
\end{tabular}




\begin{tabular}{|l|c|c|c|c|c|}
29 & Arzan Kinza R & Jl. Maccini Kidul & Laki-laki & Karyawan Swasta & 25 \\
\hline 30 & Heldy Jusi & Jl. Sungguminasa Mks & Laki-laki & Karyawan Swasta & 28 \\
\hline
\end{tabular}

Sumber: Data dari Bank Danamon Syariah Makassar

Karakteristik Responden

Karakteristik responden yaitu menguraikan deskripsi identitas responden menurut sampel penelitian yang telah ditetapkan. Salah satu tujuan dengan deskripsi tersebut adalah memberikan gambaran yang menjadi sampel dalam penelitian ini.

Dalam penelitian sampel, karakteristik responden dikelompokkan menurut jenis kelamin,pekerjaan, umur. Oleh karena itu, uraian mengenai karakteristik responden dapat diuraikan sebagai berikut:

\section{Tabel 4.2}

\section{Karakteristik Responden Berdasarkan Jenis Kelamin}

\begin{tabular}{|c|c|c|}
\hline Jenis Kelamin & Jumlah & Presentase $\%$ \\
\hline Laki-laki & 14 & $42 \%$ \\
\hline Perempuan & 16 & $58 \%$ \\
\hline Total & 30 & $100 \%$ \\
\hline
\end{tabular}

Sumber: Data diolah dari kuesioner

Dari tabel 4.2, maka dapat diketahui berdasarkan dari hasil olahan data mengenai karakteristik responden menurut jenis kelamin diatas mka jumlah responden sebanyak 16 orang berjenis kelamin perempuan atau sebesar 58\%. Dan responden berjenis kelamin laki-laki sebanyak 14 orang atau sebesar $42 \%$. Dari hasil tersebut dapat dikatakan bahwa rata-rata pegawai Bank Danamon Syariah Makassar didominasi oleh perempuan.

\section{Tabel 4.3}

\section{Karakteristik Responden Berdasarkan Pekerjaan}

\begin{tabular}{|c|c|c|}
\hline Jenis Pekerjaan & Jumlah & Presentase $\%$ \\
\hline Karyawan Swasta & 30 & $100 \%$ \\
\hline Total & 30 & $100 \%$ \\
\hline
\end{tabular}

Sumber: Data diolah dari kuesioner

Dari tabel 4.3, maka dapat diketahui bahwa pekerjaan responden adalah karyawan swasta dengan jumlah 30 orang atau sebesar $100 \%$.

\section{Tabel 4.4}

Karakteristik Responden Berdasarkan Umur

\begin{tabular}{|c|c|c|}
\hline Usia Responden & Jumlah & Presentase $\%$ \\
\hline 22 tahun & 1 & $3 \%$ \\
\hline 23 tahun & 3 & $10 \%$ \\
\hline 24 tahun & 4 & $13 \%$ \\
\hline 25 tahun & 9 & $30 \%$ \\
\hline 26 tahun & 6 & $20 \%$ \\
\hline
\end{tabular}




\begin{tabular}{|c|c|c|}
\hline 27 tahun & 2 & $7 \%$ \\
\hline 28 tahun & 3 & $10 \%$ \\
\hline 29 tahun & 1 & $3 \%$ \\
\hline 30 tahun & 1 & $3 \%$ \\
\hline Total & 30 & $100 \%$ \\
\hline
\end{tabular}

Sumber: Data diolah dari kuesioner

Dari tabel 4.4, maka dapat diketahui bahwa responden terbanyak berusia 25 tahun sebanyak 9 responden atau sebesar 30\%.

Berdasarkan hasil olahan data diatas mengenai karakteristik responden berdasarkan umur, maka jumlah responden terbesar adalah berusia 25 tahun sebanyak 9 responden atau sebesar 30\%. Urutan responden terbesar kedua adalah berusia 26 tahun sebanyak 6 responden atau sebesar 20\%. Sedangkan jumlah responden terkecil yaitu berusia 22 tahun sebanyak 1 orang, 29 tahun 1 orang dan 30 tahun sebanyak 1 orang.

\section{Deskripsi Jawaban Responden}

Jawaban responden terhadap pernyataan variabel sistem imbalan (X1) terhadap kinerja pegawai (Y) Seluruh responden untuk variabel X1 mengenai sistem imbalan terhadap kinerja pegawai berdasarkan kuesioner atau angket yang diberikan yaitu sejumlah 550 dilihat dari hasil perhitungan sebanyak 30 responden. Jawaban responden terhadap pernyataan terkait variabel lingkungan kerja (X2) terhadap kinerja pegawai $(\mathrm{Y})$

Seluruh responden untuk variabel X2 mengenai lingkungan kerja terhadap kinerja pegawai dapat dilihat hasil perhitungannya dari 30 responden berdasarkan kuesioner atau angket yang diberikan yaitu sejumlah 565. Jawaban responden terhadap pernyataan terkait variabel restrukturisasi kerja (X3) terhadap kinerja pegawai $(\mathrm{Y})$

Seluruh responden untuk variabel X3 mengenai restrukturisasi kerja terhadap kinerja pegawai dapat dilihat hasil perhitungannya dari 30 responden berdasarkan kuesioner atau angket yang diberikan yaitu sejumlah 563. Jawaban responden terhadap pernyataan Terkait kinerja pegawai (Y)

Seluruh responden untuk variabel Y mengenai kinerja pegawai dapat dilihat hasil perhitungannya berdasarkan kuesioner atau angket yang diberikan yaitu sejumlah 555 dari 30 responden.

\section{Pengujian Instrumen Penelitian}

\section{1) Uji Validitas}

Uji validitas digunakan untuk melihat ketetapan dan kecermatan dari sebuah instrument penelitian dalam fungsi ukurnya mengukur item-item pernyataan yang digunakan dalam bentuk pernyataan yang memilih korelasi positif tinggi dapat dianggap memiliki validitas yang tinggi pula.

Corrected item total correlation merupakan korelasi antar skor total item, sehingga interpretasinya dengan mengkonsultasikan nilai kritis $\mathrm{r}$-tabel, jika $\mathrm{r}$ hitung $>$ nilai kritis $\mathrm{r}$-tabel product moment maka instrument dinyatakan valid atau dapat dikatakan bahwa item pernyataan dari cerminan setiap variabel dalam penelitian ini keberadaannya pada instrument penelitian dinyatakan valid (sah).

Adapun hasil uji validitas dari setiap item pernyataan variabel dalam penelitian ini sebagai berikut:

\section{Tabel 4.5}

\section{Hasil Uji Validitas}




\section{Descriptive Statistics}

\begin{tabular}{|l|l|l|l|}
\hline & Mean & Std. Deviation & N \\
\hline Sistem Imbalan (X1) & 21.50 & 2.330 & 30 \\
Lingkungan Kerja (X2) & 22.17 & 2.422 & 30 \\
Restrukturisasi Kerja (X3) & 21.93 & 2.449 & 30 \\
Kinerja Pegawai (Y) & 21.40 & 1.694 & 30 \\
Total_Jawaban & 87.00 & 7.007 & 30 \\
\hline
\end{tabular}

\section{Correlations}

\begin{tabular}{|cc|c|c|c|c|c|}
\hline & & $\begin{array}{c}\text { Sistem } \\
\text { Imbalan } \\
(\mathrm{X} 1)\end{array}$ & $\begin{array}{c}\text { Lingkungan } \\
\text { Kerja } \\
(\mathrm{X} 2)\end{array}$ & $\begin{array}{c}\text { Restrukturisasi } \\
\text { Kerja } \\
(\mathrm{X} 3)\end{array}$ & $\begin{array}{c}\text { Kinerja } \\
\text { Pegawai } \\
(\mathrm{Y})\end{array}$ & $\begin{array}{c}\text { Total } \\
\text { Jawaban }\end{array}$ \\
\hline Sistem & Pearson Correlation & 1 & $.473^{* *}$ & $.622^{* *}$ & $.646^{* *}$ & $.870^{* *}$ \\
Imbalan (X1) & Sig. (2-tailed) & & .008 & .000 & .000 & .000 \\
& $\mathrm{~N}$ & 30 & 30 & 30 & 30 & 30 \\
\hline Lingkungan & Pearson Correlation & $.473^{* *}$ & 1 & $.519^{* *}$ & .227 & $.739^{* *}$ \\
Kerja (X2) & Sig. (2-tailed) & .008 & 1. & .003 & .228 & .000 \\
& $\mathrm{~N}$ & 30 & 30 & 30 & 30 & 30 \\
\hline Restrukturisasi & Pearson Correlation & $.622^{* *}$ & $.519^{* *}$ & 1 & $.406^{*}$ & $.834^{* *}$ \\
Kerja (X3) & Sig. (2-tailed) & .000 & .003 & .026 & .000 \\
& $\mathrm{~N}$ & 30 & 30 & 30 & 30 & 30 \\
\hline Kinerja & Pearson Correlation & $.646^{* *}$ & .227 & $.406^{*}$ & 1 & $.677^{* *}$ \\
Pegawai (Y) & Sig. (2-tailed) & .000 & .228 & .026 & & .000 \\
& $\mathrm{~N}$ & 30 & 30 & 30 & 30 & 30 \\
\hline Total_Jawaba & Pearson Correlation & $.870^{* *}$ & $.739^{* *}$ & $.834^{* *}$ & $.677^{* *}$ & 1 \\
$\mathrm{n}$ & Sig. (2-tailed) & .000 & .000 & .000 & .000 & 30 \\
\hline & $\mathrm{N}$ & 30 & 30 & 30 & 30 & 30 \\
\hline
\end{tabular}

**. Correlation is significant at the 0.01 level (2-tailed).

*. Correlation is significant at the 0.05 level (2-tailed).

Sumber: Data diolah dengan SPSS 2018

Dasar pengambilan keputusan dalam uji validitas adalah:

Jika $r$ hitung $>\mathrm{r}$ tabel $=$ valid

Jika $\mathrm{r}$ hitung $<\mathrm{r}$ tabel $=$ tidak valid

Pada tabel 4.5 di atas yang menjadi sampel adalah 30 orang. Rata-rata jawaban skor pernyataan X1 variabel sistem imbalan sebesar 21.50 ; pernyataan X2 lingkungan kerja sebesar 21.17; pernyataan X3 restrukturisasi kerja sebesar 21.93 ; dan pernyataan Y kinerja pegawai sebesar 21.40. 
Hasil uji validitas dari kelima butir pernyataan variabel sistem imbalan diperoleh Corrected Item Total Correlation $\mathrm{r}$ hitung $(0.870)>\mathrm{r}$ tabel $(0,374)$. Hal ini berarti setiap butir pernyataan dari variabel Teistis yang digunakan dalam penelitian ini adalah valid (sah).

Hasil uji validitas dari kelima butir pernyataan variabel lingkungan kerja diperoleh Corrected Item Total Correlation $\mathrm{r}$ hitung $(0.739)>\mathrm{r}$ tabel $(0,374)$. Hal ini berarti setiap butir pernyataan dari variabel $\mathrm{X} 1$ yang digunakan dalam penelitian ini adalah valid (sah).

Hasil uji validitas dari kelima butir pernyataan variabel restrukturisasi kerja diperoleh Corrected Item Total Correlation $\mathrm{r}$ hitung $(0.834)>\mathrm{r}$ tabel $(0,374)$. Hal ini berarti setiap butir pernyataan dari variabel $\mathrm{X} 2$ yang digunakan dalam penelitian ini adalah valid (sah).

Hasil uji validitas dari kelima butir pernyataan variabel Restrukturisasi kerja diperoleh Corrected Item Total Correlation $\mathrm{r}$ hitung $(0.834)>\mathrm{r}$ tabel $(0,374)$. Hal ini berarti setiap butir pernyataan dari variabel $\mathrm{X} 3$ yang digunakan dalam penelitian ini adalah valid (sah).

Maka sebagai kesimpulan bahwasanya seluruh item pernyataan pada kuesioner dalam penelitian ini dinyatakan layak dijadikan instrument dalam mengukur data penelitian.

\section{2) Uji Reliabilitas}

Instrument dalam penelitian ini dikatakan reliabel atau handal apabila dipergunakan beberapa kali untuk mengukur objek yang sama sehingga menghasilkan data yang sama.

Adapun hasil uji reliabilitas dari setiap item pernyataan variabel yang digunakan dalam penelitian ini adalah sebagai berikut:

Tabel 4.6

Hasil Uji Reliabilitas

Reliability Statistics

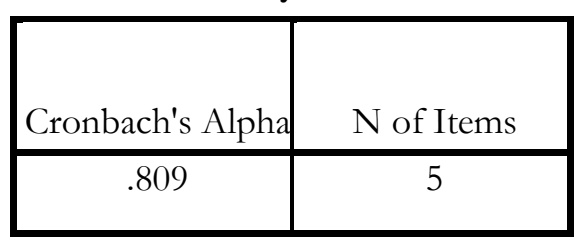

Sumber: Data diolah dengan SPSS, 2018

Dasar pengambilan keputusan dalam uji reliabilitas adalah:

Jika alpha $>\mathrm{r}$ tabel $=$ konsisten (handal)

Jika alpha $<\mathrm{r}$ tabel $=$ tidak konsisten

Data pada tabel 4.6 menunjukkan hasil analisis uji reliabilitas, dimana nilai $r$ hitung dari 20 butir pernyataan $>\mathrm{r}$ tabel $(0,374)$. Hal ini berarti setiap pernyataan dari variabel yang digunakan dalam penelitian ini dapat dikatakan bahwa instrument penelitian yang digunakan dalam fungsi ukurnya tidak menimbulkan arti ganda sehingga terjamin konsistensinya dalam mengukur Quality of Work Life (QWL) terhadap kinerja pegawai pada Bank Danamon Syariah Makassar. 
Kemudian nilai cronbach's alpha dari keseluruhan butir pernyataan dalam instrument penelitian diperoleh sebesar 0.809 yang menunjukkan tingkat konsistensi (kehandalan) dan instrument penelitian yang digunakan adalah sebesar $80.9 \%$. Artinya apabila kuesioner dalam penelitian ini akan digunakan secara berulang-ulang pada populasi akan memberikan nilai objektifitas, stabilitas, akurasi dan konsistensi yang tinggi untuk mengukur pengaruh kinerja pegawai.

\section{Pengujian Asumsi Klasik}

\section{1) Uji Normalitas}

Uji normalitas dilakukan untuk melihat apakah model regresi yang digunakan memiliki residual yang terdistribusi secara normal atau tidak. Apabila didapatkan residual yang tidak tersebar secara normal pada suatu regresi, maka akan menghasilkan regresi yang tidak baik atau tidak konsisten dan efisien.

Data pengambilan keputusan data dikatakan terdistribusi normal, jika data atau titik menyebar di sekitar garis diagonal dan mengikuti arah garis diagonal. Sebaliknya dikatakan tidak terdistribusi normal, jika data atau titik menyebar jauh dari arah garis atau tidak mengikuti diagonal.

Adapun hasil pengujian grafis normalitas dalam penelitian ini dapat dilihat pada grafik berikut.

\section{Grafik 4.1}

\section{Hasil Uji Normalitas}

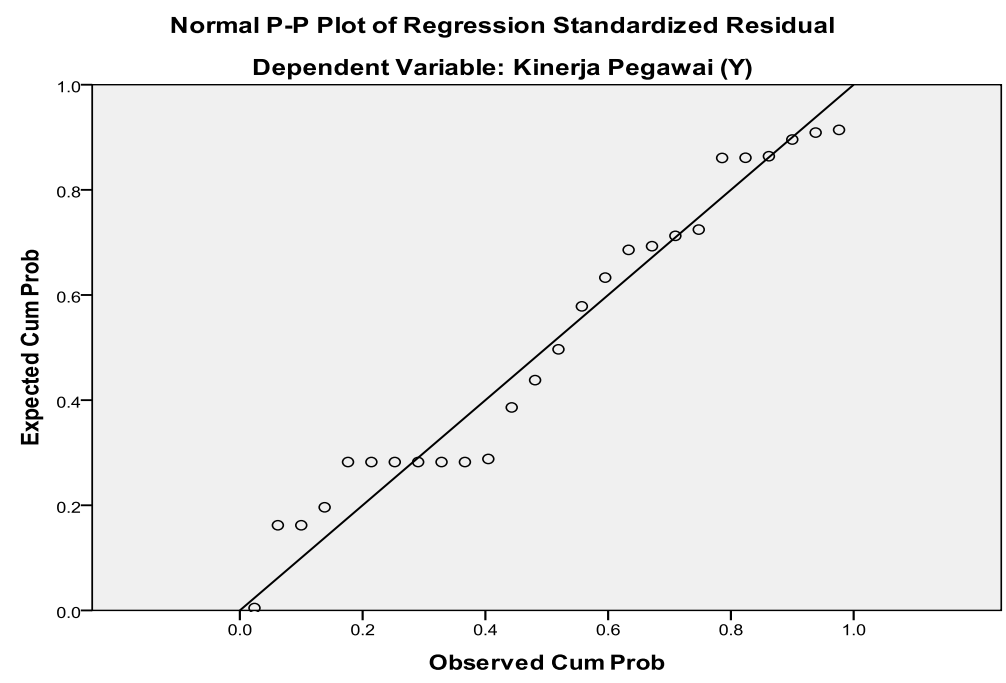

Sumber: Data diolah dengan SPSS, 2018

Grafik 4.1 menunjukkan bahwa sebaran titik berada di sekitar garis diagonal dan beberapa mengikuti arus garis diagonal. Pengujian distribusi data yang dilakukan dengan metode grafis ini menunjukkan hasil yang dapat disimpulkan bahwa model regresi layak digunakan untuk mnegukur pengaruh Qualiti of Work Life (QWL) terhadap kinerja pegawai pada Bank Danamon Syariah Makassar. karena telah memenuhi asumsi normalitas.

\section{2) Uji Multikolinearitas}

Keberadaan multikolinearitas dalam suatu regresiakan mengganggu hasil regresi penelitian, sehingga tidak menghasilkan parameter yang efisien dan efektif yang akan membuat kesalahan dalam parameter yang dihasilkan. 
Dasar pengambilan keputusan keberadaan multikolinearitas dapat dilihat melalui nilai VIF (Variance Inflation Factors) atau nilai toleransinya, yakni apabila nilai:

Tolerance $>0,10=$ Tidak Terjadi Multikolinearitas

Tolerance $<0,10=$ Terjadi Multikolinearitas

VIF $<10,00=$ Tidak Terjadi Multikolinearitas

VIF $>10,00=$ Terjadi Multikolinearitas

Adapun hasil perhitungan nilai VIF atau toleransi yang dikatakan untuk regresi dalam penelitian ini adalah sebagai berikut:

Tabel 4.7

Hasil Uji Multikolineritas

\section{Coefficients $^{\mathrm{a}}$}

\begin{tabular}{|c|c|c|}
\hline \multirow{2}{*}{ Model } & \multicolumn{2}{|c|}{ Collinearity Statistics } \\
\hline & Tolerance & VIF \\
\hline (Constant) & & \\
\hline Sistem Imbalan (X1) & .582 & 1.719 \\
\hline Lingkungan Kerja (X2) & .693 & 1.442 \\
\hline Restrukturisasi Kerja (X3) & .548 & 1.826 \\
\hline
\end{tabular}

a. Dependent Variable: Kinerja Pegawai $(\mathrm{Y})$

Sumber: Data diolah dengan SPSS, 2018

Dari tabel 4.7 dapat dilihat bahwa nilai tolerance untuk nilai variabel X1 yaitu 0.582, untuk nilai variabel X2 yaitu 0.693, dan untuk nilai variabel X3 yaitu 0.548 , semua nilai tolerance dari uji multikolineritas variabel independen (sistem imbalan, lingkungan kerja, restrukturisasi kerja) menunjukkan $>0,10$, atau dengan kata lain nilai tolerance dari variabel independen lebih besar dari 0,10.

Kemudian nilai VIF untuk variabel X1 sebesar 1.719, untuk variabel X2 sebesar 1.442, dan untuk variabel X3 sebesar 1.826, ini menunjukkan semua variabel independen (sistem imbalan, lingkungan kerja, restrukturisasi kerja) memiliki VIF < 10. Dengan demikian dapat disimpulkan bahwa tidak terjadi adanya penyimpangan asumsi klasik multikolineritas antara variabel independen dan model.

Hasil uji multikolinearitas pada tabel di atas menunjukkan bahwa semua variabel independen memiliki nilai VIF yang lebih kecil dari 10 dan nilai toleransi yang lebih besar dari 0,10. Ini menunjukkan bahwa indikasi keberadaan multikolinearitas pada persamaan yang dilakukan tidak tebukti atau tidak terdapat multikolinearitas dalam persamaan yang dilakukan atau hubungan yang terjadi antar variabel independen (sistem imbalan, lingkungan kerja, restrukturisasi kerja) dapat ditoleransi sehingga tidak akan mengganggu hasil regresi.

\section{Pembahasan hasil Penelitian}

Berdasarkan hasil asumsi klasik yang meliputi uji normalitas dan uji multikolinearitas menunjukkan bahwa regresi berganda yang distimasi telah memenuhi syarat asumsi-asumsi klasik sehingga diharapkan hasilnya akan baik dalam menganalisis pengaruh Qualiti of Work Life (QWL) terhadap kinerja pegawai pada Bank Danamon Syariah Makassar. Pengujian terhadap agresi yang diperoleh dilakukan pengujian secara simultan dengan 
menggunakan uji - F dan pengujian secara parsial dengan menggunakan uji - T Untuk lebih jelasnya akan diuraikan sebagai berikut:

Pada analisa data diperlukan suatu persamaan garis berdasarkan suatu rumus matematika yang menunjukkan hubungan antara variabel independen atau variabel yang mempengaruhi dengan variabel dependen atau yang dipengaruhi. Variabel yang mempengaruhi disebut variabel X1,X2, X3 dan variabel yang dipengaruhi disebut variabel Y.

Regresi menunjukkan hubungan antara variabel-variabel yang satu dengan variabel yang lainnya dimana variabel yang satu mempengaruhi variabel yang lain. Analisis regresi linear digunakan untuk mengetahui ada tidaknya pengaruh Qualiti of Work Life (QWL) terhadap kinerja pegawai pada Bank Danamon Syariah Makassar.

Teknik yang digunakan untuk pengujian terhadap ada tidaknya pengaruh atau hubungan variabel dalam penelitian ini.

Model regresi yang dikembangkan adalah:

$\mathrm{Y}=\mathrm{a}+\beta_{1} \mathrm{x}_{1}+\beta_{2} \mathrm{x}_{2}+\beta_{3} \mathrm{x}_{3}$

Dimana:

$\mathrm{Y}=$ Kinerja pegawai (variabel dependen atau nilai yang diprediksikan)

a $\quad$ Konstanta (nilai yang tidak berubah)

$\mathrm{b}_{1}, \mathrm{~b}_{2}, \mathrm{~b}_{3} \quad=$ Koefisien Regresi Berganda

$\mathrm{x}_{1}=$ Sistem Imbalan (variabel independen atau variabel yang mempengaruhi variabel independen)

$\mathrm{x}_{2}=$ Lingkungan Kerja (variabel independen atau variabel yang mempengaruhi variabel independen)

$\mathrm{x}_{3}=$ Restrukturisasi kerja (variabel independen atau variabel yang mempengaruhi variabel independen)

\section{Analisis Regresi Linear Berganda}

Untuk mengetahui ada atau tidak adanya pengaruh karakteristik sharia marketing terhadap minat menabung, digunakan regresi linear.

Adapun hasil regresi berganda adalah sebagai berikut:

Tabel 4.8

Hasil Perhitungan Regresi Berganda

Coefficients $^{\mathrm{a}}$

\begin{tabular}{|c|l|c|c|c|c|}
\hline \multirow{2}{*}{ Model } & \multicolumn{2}{|c|}{$\begin{array}{c}\text { Unstandardized } \\
\text { Coefficients }\end{array}$} & $\begin{array}{c}\text { Standardized } \\
\text { Coefficients }\end{array}$ & & \\
\cline { 2 - 5 } & & $\begin{array}{c}\text { Std. } \\
\text { Error }\end{array}$ & Beta & $\mathrm{T}$ & Sig. \\
\hline (Constant) & 11.976 & 2.773 & & 4.318 & .000 \\
Sistem Imbalan (X1) & .488 & .141 & .671 & 3.450 & .002 \\
Lingkungan Kerja (X2) & .081 & .125 & .116 & .650 & .521 \\
Restrukturisasi Kerja & .033 & .139 & .048 & .239 & .813 \\
(X3) & & & & & \\
\hline
\end{tabular}

a. Dependent Variable: Kinerja Pegawai (Y) 
Sumber: Data diolah dengan SPSS, 2018

Dari tabel 4.8 diatas dapat dilihat dari tabel B Constant adalah 11.976, variabel X1 yaitu 0.488, variabel X2 yaitu 0.081, dan variabel X3 yaitu 0.033. Berdasarkan hasil penelitian diatas, diperoleh persamaan regresi sebagai berikut:

$$
\begin{aligned}
& \mathrm{Y}=\mathrm{a}+\beta_{1 \mathrm{X}_{1}}+\beta_{2 \mathrm{X}_{2}}+\beta_{3 \mathrm{X}_{3}} \\
& \mathrm{Y}=11.976+0.488 \times 1+0.081 \times 2+0.033 \times 3
\end{aligned}
$$

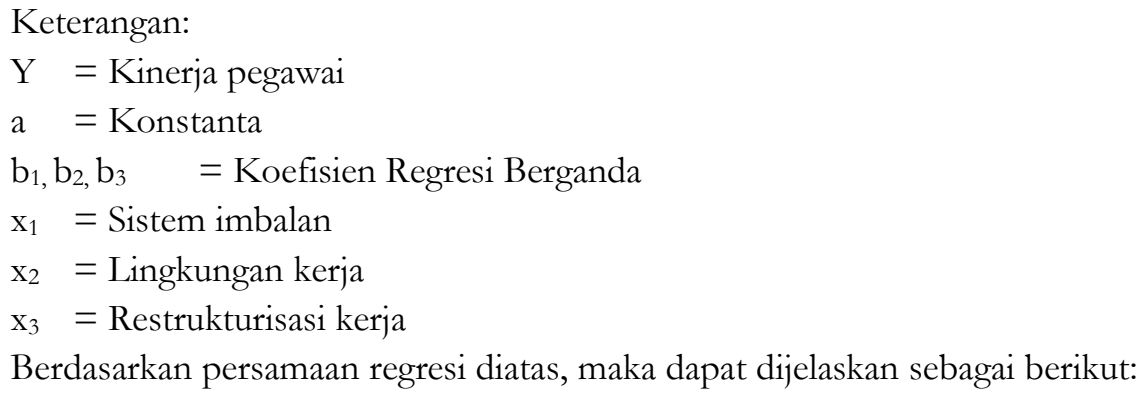

\section{1) Nilai Konstanta (a)}

Data nilai koefisien konstanta sebesar 11.976 artinya jika X1, X2 dam X3 nilainya nol, maka tingkat pengaruh kinerja pegawai di Bank Danamon Syariah Makassar adalah sebesar 11.976.

\section{2) Sistem Imbalan}

Koefisien Regresi $\mathrm{X}_{1}\left(\Omega_{1}\right)$ sebesar 0.488 merupakan penaksir parameter variabel sistem imbalan terhadap kinerja pegawai. Nilai ini menunjukkan apabila nilai variabel independen lain nilainya tetap, maka variabel Teistis meningkat 1 point maka kinerja pegawai pada Bank Danamon Syariah Makassar mengalami peningkatan sebesar 0.488 . T statistiknya adalah positif, artinya kedua variabel tersebut terjadi hubungan positif antara persepsi sistem imbalan dengan kinerja pegawai.

\section{3) Lingkungan Kerja}

Koefisien Regresi X2 $\left(ß_{2}\right)$ sebesar 0.081 merupakan penaksir parameter variabel lingkungan kerja terhadap kinerja pegawai. Nilai ini menunjukkan apabila nilai variabel independen lain nilainya tetap, maka variabel sistem imbalan meningkat 1 point maka kinerja pegawai pada Bank Danamon Syariah Makassar mengalami peningkatan sebesar 0.041. T statistiknya adalah positif, artinya kedua variabel tersebut terjadi hubungan positif antara persepsi lingkungan kerja terhadap kinerja pegawai.

\section{4) Restrukturisasi Kerja}

Koefisien Regresi X3 $\left(\Omega_{3}\right)$ sebesar 0.033 merupakan penaksir parameter variabel restrukturisasi kerja terhadap kinerja pegawai. Nilai ini menunjukkan apabila nilai variabel independen lain nilainya tetap, maka variabel Realistis meningkat 1 point maka kinerja pergawai pada Bank Danamon Syariah Makassar mengalami peningkatan sebesar 0.037. T statistiknya adalah positif, artinya kedua variabel tersebut terjadi hubungan positif antara persepsi restrukturisasi kerja dengan kinerja pegawai.

Untuk mengetahui signifikan variabel independen terhadap variabel dependen dilakukan pengujian-pengujiannya yaitu sebagai berikut:

\section{Pengujian Hipotesis secara Parsial (Uji T)}

Uji T adalah suatu tes statistik yang memungkinkan kita membandingkan dua skor rata-rata, untuk menentukan probabilitas (peluang) bahwa perbedaan antara dua skor rata-rata merupakan perbedaan 
yang nyata bukan perbedaan yang terjadi secara kebetulan. Pengujian variabel independen secara individu yang dilakukan untuk melihat siginifikansi dari pengaruh variabel independen terhadap variabel dependen, maksudnya yakni apakah model regresi variabel independen X1, X2, dan X3 secara parsial berpengaruh siginifikan positif terhadap variabel dependepen $(Y)$.

Pengujian ini dilakukan dengan menggunakan hipotesis sebagai berikut:

$H_{0}: \beta_{1}, \beta_{2}$, dan $\beta_{3}=0$ atau koefisien $\beta_{1,} \beta_{2}$, dan $\beta_{3}$ tidak mempengaruhi $Y$

$H_{1}: \beta_{1}, \beta_{2}$, dan $\beta_{3} \neq 0$ atau koefisien $\beta_{1}, \beta_{2}$, dan $\beta_{3}$ mempengaruhi $Y$

Dimana: $\mathrm{P}$-Value $<0,05$ maka $\mathrm{H}_{0}$ ditolak

$\mathrm{H}_{1}$ diterima

$\mathrm{P}-$ Value $>0,05$ maka $\mathrm{H}_{0}$ diterima

$\mathrm{H}_{1}$ ditolak

$\mathrm{H}_{0}=$ sistem imbalan, lingkungan kerja dan retrukturisasi kerja tidak mempengaruhi Kinerja Pegawai

$\mathrm{H}_{1}=$ sistem imbalan, lingkungan kerja dan retrukturisasi kerja mempengaruhi Kinerja Pegawai.

Tabel 4.9

Pengujian secara Parsial (Uji-T)

Coefficients $^{\mathrm{a}}$

\begin{tabular}{|c|c|c|r|r|r|}
\hline \multirow{2}{*}{ Model } & \multicolumn{2}{|c|}{$\begin{array}{c}\text { Unstandardized } \\
\text { Coefficients }\end{array}$} & $\begin{array}{r}\text { Standardized } \\
\text { Coefficients }\end{array}$ & & \\
\cline { 2 - 4 } & \multicolumn{1}{|c|}{$\mathrm{B}$} & Std. Error & Beta & T & Sig. \\
\hline (Constant) & 11.976 & 2.773 & & 4.318 & .000 \\
Sistem Imbalan (X1) & .488 & .141 & .671 & 3.450 & .002 \\
Lingkungan Kerja (X2) & .081 & .125 & .116 & .650 & .521 \\
Restrukturisasi Kerja & .033 & .139 & .048 & .239 & .813 \\
(X3) & & & & & \\
\hline
\end{tabular}

a. Dependent Variable: Kinerja Pegawai (Y)

Sumber: Data diolah dengan SPSS, 2018

Dari tabel 4.9 diketahui bahwa nilai t hitung sebesar 4.318 dengan signifikansi sebesar 0,000 karena $\mathrm{P}$ - Value $<0,05 \mathrm{H}_{1}$ diterima yang berarti bahwa Quality of Work Life (QWL) berpengaruh positif terhadap kinerja pegawai.

\section{Pengujian Hipotesis secara Simultan (Uji F)}

Uji F berfungsi untuk mengetahui apakah variabel independen (X1, X2, dan X3) secara bersamasama berpengaruh secara signifikan terhadap variabel dependen (Y). Serta untuk mengetahui apakah model regresi dapat digunakan untuk memprediksi variabel dependen $(\mathrm{Y})$ atau tidak.

Tabel 4.10

Pengujian secara Simultan (Uji-F) 


\section{ANOVA ${ }^{b}$}

\begin{tabular}{|c|c|c|c|c|c|c|}
\hline \multicolumn{2}{|r|}{ Model } & Sum of Squares & Df & Mean Square & F & Sig. \\
\hline 1 & Regression & 35.544 & 3 & 11.848 & 6.464 & $.002^{\mathrm{a}}$ \\
\hline & Residual & 47.656 & 26 & 1.833 & & \\
\hline & Total & 83.200 & 29 & & & \\
\hline
\end{tabular}

a. Predictors: (Constant), Restrukturisasi Kerja (X3), Lingkungan Kerja (X2), Sistem Imbalan (X1)

\section{b. Dependent Variable: Kinerja Pegawai (Y)}

Sumber: Data diolah dengan SPSS, 2018

Dari tabel 4.10 perhitungan uji statistik yang dilakukan maka diperoleh nilai F-hitung sebesar 6.464 dengan tingkat siginifikansi 0,002. Karena $\mathrm{P}-$ Value $<0,05 \mathrm{maka}_{1}$ diterima, dengan kata lain koefisien $\beta_{1}, \beta_{2}$, dan $\beta_{3}$ mempengaruhi $Y$ secara bersama-sama sehingga dapat dikatakan bahwa model regresi dapat dipakai atau digunakan untuk memprediksi kinerja pegawai.

Dengan demikian, keputusannya adalah menerima hipotesis yang menyatakan bahwa terdapat pengaruh positif dan siginifikan antara variable sistem imbalan (X1), kinierja pegawai (X2) dan retrukturisasi kerja (X3) terhadap kinerja pegawai (Y) di Bank Danamon Syariah Makassar.

\section{1) Koefisien Determinasi (Adjusted $R$ Square)}

Koefisien Determinasi (Adjusted R Square) merupakan besarnya kontribusi variabel bebas terhadap variabek atau dengan kata lain berfungsi untuk melihat sejauh mana keseluruhan variabel $\mathrm{X}$ (independen) dapat menjelaskan variabel dependen (Y). meskipun demikian, koefisien determinasi sedikit memiliki kelemahan disebabkan karena biasnya terhadap jumlah variabel bebas yang dimasukkan dengan model regresi. Kelemahan ini terlihat disetiap penambahan satu variabel bebas dan jumlah pengamatan dalam model akan meningkatkan nilai $R$ Square, walaupun variabel yang dimasukkan tersebut tidak memiliki pengaruh yang signifikan terhadap variabel terikatnya. Solusi terbaik untuk mengurangi kelemahan tersebut maka digunakan koefisien determinasi yang terlah disesuaikan Adjusted R Square (R2).

Penyesuain koefisien determinasi berarti bahwa koefisien tersebut telah dikoreksi dengan mamsukkan jumlah variabel dan ukuran sampel yang digunakan. Koefisien determinasi yang digunakan dan telah disesuaikan maka nilai koefisien determinasi yang disesuaikan itu dapat dapat naik atau turun oleh adanya penambahan variabel baru dalam model.

Koefisien determinasi digunakan untuk mencari seberapa besar variasi variabel independen dapat menjelaskan secara keseluruhan variasi variabel independen. Koefisien determinasi mengukur seberapa besar pengaruh variabel independen secara keseluruhan terhadap naik turunnya variasi nilai variabel independen.

Untuk lebih lengkapnya hasil uji Adjusted $\mathrm{R}$ Square $\left(\mathrm{R}^{2}\right.$ adj) dapat dilihat pada tabel berikut:

\section{Tabel 4.11}

\section{Hasil Pengujian Adjusted R Square}




\begin{tabular}{|c|c|c|c|c|}
\hline Model & & & & \\
& $\mathrm{R}$ & R Square & Adjusted R Square & Std. Error of the Estimate \\
\hline 1 & $.654^{a}$ & .427 & .361 & 1.354 \\
\hline
\end{tabular}

a. Predictors: (Constant), Restrukturisasi Kerja (X3), Lingkungan Kerja (X2), Sistem Imbalan (X1)

b. Dependent Variable: Kinerja Pegawai (Y)

Sumber: Data diolah dengan SPSS, 2018

Berdasarkan tabel 11 dapat dilihat nilai Adjusted R Square sebesar 0,361 atau sebesar 36,1\%, yang dapat diartikan bahwa 36,1\% kinerja pegawai di Bank Danamon Syariah Makassar dipengaruhi oleh sistem imbalan, lingkungan kerja, dan restrukturisasi kerja. Sedangkan sisanya sebesar $63,9 \%(100 \%-$ $36,1 \%$ ) dipengaruhi oleh faktor lain yang tidak termasuk dalam penelitian ini.

\section{2) Korelasi Ganda $\mathbf{R}^{2}$}

Analisis ini digunakan untuk mengetahui hubungan antara dua atau lebih variabel independen (X1, $\mathrm{X} 2$, dan X3) terhadap variabel (Y) secara serentak. Koefisien ini menunjukkan seberapa besar hubungan yang terjadi antara variabel independen $(X 1, X 2$, dan X3) secara serentak terhadap variabel dependen $(\mathrm{Y})$. Nilai $\mathrm{R}$ berkisar antara 0 sampai 1 , nilai mendekati 1 berarti hubungan yang terjadi semakin tinggi, sebaliknya nilai semakin mendekati 0 maka hubungan yang terjadi semakin lemah. Pedoman untuk memberikan interpretasi koefisien korelasi adalah sebagai berikut:

$$
\begin{aligned}
& 0,00-0,199=\text { sangat rendah } \\
& 0,20-0,399=\text { rendah } \\
& 0,40-0,599=\text { sedang } \\
& 0,60-0,799=\text { tinggi } \\
& 0,80-1,000=\text { sangat tinggi }
\end{aligned}
$$

Tabel 4.12

Pengujian Korelasi Ganda $\mathbf{R}^{2}$

Model Summaryb

\begin{tabular}{|c|c|c|c|c|}
\hline Model & $\mathrm{R}$ & R Square & Adjusted R Square & Std. Error of the Estimate \\
\hline 1 & $.654^{\mathrm{a}}$ & .427 & .361 & 1.354 \\
\hline
\end{tabular}

a. Predictors: (Constant), Restrukturisasi Kerja (X3), Lingkungan Kerja (X2), Sistem Imbalan (X1)

b. Dependent Variable: Kinerja Pegawai (Y)

Sumber: Data diolah dengan SPSS, 2018

Berdasarkan tabel 4.12 hasil uji regresi angka R sebesar 0.654. Dapat diukur dari pedoman untuk memberikan interpretasi koefisien korelasi, angka 0.654 lebih besar dari 0,60 dan berada pada korelasi atau hubungan yang tinggi dimana pada pedoman tersebut dapat dilihat nilainya sebesar 0,60 - 0,799 merupakan hubungan yang tinggi. Hal ini menunjukkan bahwa terdapat hubungan yang tinggi antara variabel independen (X1, X2, dan X3) terhadap variabel dependen (Y). 


\section{Pembahasan hasil Quality Of Work Life (QWL)}

Pembahasan mengenai Pengaruh Quality of Work Life (QWL) antara lain Sistem Imbalan, Restrukturisasi Kerja dan Lingkungan Kerja terhadap Kinerja Pegawai akan dibahas sebagai berikut:

\section{a. Sistem Imbalan Terhadap Kinerja Pegawai}

Dapat dilihat pada hasil output uji t tersebut, diketahui bahwa nilai koefisien regresi variabel sistem imbalan $\left(\mathrm{X}_{1}\right)$ adalah sebesar 0,488 bernilai positif, sehingga dapat dikatakan bahwa sistem imbalan $\left(\mathrm{X}_{1}\right)$ berpengaruh positif terhadap Kinerja Pegawai. Dengan demikian dapat diartikan bahwa semakin meningkat penerapan konpensasi seperti gaji yang memenuhi kebutuhan hidup pegawai, pemberian gaji tepat waktu, gaji sesuai dengan pekerjaan, gaji sesuai yang diharapkan pegawai, pemberian bonus dan tunjangan sosial, maka variabel sistem imbalan terbukti berpengaruh positif terhadap Kinerja Pegawai pada Bank Danamon Syariah Makassar.

Bila dilihat dari sebagian besar responden yang menyatakan persetujuannya, artinya Sistem Imbalan Bank Danamon Syariah Makassar telah sesuai sesuai dengan keinginan pegawai. Dari hasil wawancara yang dilakukan oleh pegawai dengan jabatan Marketing mengaku bahwa Sistem Imbalan yang diterapkan di organisasinya sudah bagus sehingga bernilai positif dan berpengaruh terhadap kinerja pegawai. Sehingga hasil dari temuan ini tidak sejalan dengan penemuan sebelumnya yang dilakukan oleh inceng pratiwi yang menyatakan sistem imbalan tidak mempengaruhi kinerja pegawai. (Rokhayati et al., 2020)

Sistem imbalan yang inovatif adalah sistem imbalan yang diberikan kepada pegawai yang memungkinkan mereka untuk memuaskan berbagai kebutuhannya sesuai dengan standar hidup pegawai bersangkutan dan sesuai dengan standar penggajian yang berlaku untuk pekerja. Sistem imbalan ini mencakup gaji, tunjangan, bonus-bonus, dan berbagai fasilitas lain sebagai imbalan jerih payah pegawai dalam bekerja. (Aljuhri, 2012) Dan dari hasil ini,

\section{b. Lingkungan Kerja Terhadap Kinerja Pegawai}

Hasil output pada tabel 10, dapat diketahui bahwa nilai koefisien regresi variabel lingkungan kerja $\left(\mathrm{X}_{2}\right)$ adalah sebesar 0,081 bernilai negatif, sehingga dapat dikatakan bahwa lingkungan kerja $\left(\mathrm{X}_{2}\right)$ tidak berpengaruh positif terhadap kinerja pegawai. Lingkungan kerja meliputi kondisi pencahayaan ruangan, kebersihan, suasana dan desain ruang kerja, hubungan antar pegawai maupun atasan tidak sesuai yang di inginkan pegawai.

Hasil penelitian ini menunjukkan bahwa pegawai Bank Danamon Syariah Makassar memiliki Lingkungan kerja yang tidak mendukung para pegawai. Lingkungan kerja merupakan kondisi-kondisi di sekitar pegawai baik itu dari segi fisik maupun non fisik. Maka dari itu, suatu organisasi wajib untuk menciptakan lingkungan kerja yang nyaman bagi pegawainya.

Pengaruh positif dapat diartikan bahwa semakin meningkat penerapan variabel lingkungan kerja maka meningkat pula kinerja pegawai pada Bank Danamon Syariah Makassar.

Salah satu harapan bagi setiap pekerja yaitu bisa merasakan lingkungan yang baik yang dapat menunjang segala aktifitas dalam melakukan tugasanya. Seperti halnya Pegawai Bank Danamon Syariah Makassar dengan menciptakan lingkungan yang aman, bersih dan sejahtera, dan hal lain yang terkait. Artinya lingkungan kerja ini sangat mempengaruhi kinerja pegawai atau dengan kata lain, jika penerapan lingkungan kerja yang diberikan kepada pegawai sesuai dengan apa yang diharapkan, maka kinerja pegawai juga akan meningkat. (Manajemen, 2019) 


\section{Syarif Al Qadri, Moh. Yasin Soumena}

\section{c. Restrukturisasi Kerja Terhadap Kinerja pegawai}

Pada hasil output uji t tersebut, dapat diketahui bahwa nilai koefisien regresi variabel Restrukturisasi $\left(\mathrm{X}_{3}\right)$ adalah sebesar 0,033 bernilai negatif, sehingga dapat dikatakan bahwa Restrukturisasi $\left(\mathrm{X}_{3}\right)$ tidak berpengaruh positif terhadap kinerja pegawai. Pengaruh positif dapat diartikan bahwa semakin meningkat pengaruh variabel Restrukturisasi maka meningkat pula kinerja pegawai pada Bank Danamon Syariah

Dalam hasil penelitian menunjukan bahwa Bank Danamon syariah Makassar memberikan pelatihan atau training untuk meningkatkan keterampilan pegawai agar dapat memberikan kinerja yang lebih professional bagi organisasi. Karena semakin baik restrukturisasi kerja pegawai, maka akan semakin baik pula kinerja yang dihasilkan pegawai.

Dari hasil wawancara oleh pegawai dengan jabatan backoffice mengatakan Restrukturisasi kerja dilakukan oleh bank untuk memperluas kesempatan pengembangan profesionalitas pegawai. Selain itu pengaturan jadwal kerja, kesempatan pengembangan karier, tugas yang sesuai pendidikan sebelumnya, pemberian apresiasi, bekerja sama dalam kelompok kerja / work group, ketersediaan SOP, peraturan, pengarahan, bimbingan serta kesempatan untuk kemampuan bagian dari restrukturisasi kerja. Namun restrukturisasi dalam Bank danamon Syariah Makassar yang di terapkan belum sepenuhnya terlaksana dengan baik. (Lasmawati, 2020)

Persepsi variabel Restrukturisasi Kerja yang berpengaruh negatif, hal ini mengidentifikasikan bahwa pegawai di Bank Danamon Syariah Makassar belum bersikap profesional dalam melakukan pekerjaannya serta hal lain yang terkait ternyata berpengaruh terhadap kinerja pegawai. Artinya Restrukturisasi Kerja ini sangat mempengaruhi kinerja pegawai.

Dengan demikian, adapun kesimpulan dari hasil uji t pada tabel 4.9 bahwa Quality Of Work Life yang terdiri dari variabel Sistem Imbalan $\left(\mathrm{X}_{1}\right)$ berpengaruh positif dan signifikan, kemudian Lingkungan Kerja $\left(\mathrm{X}_{2}\right)$, dan Restrukturisasi Kerja $\left(\mathrm{X}_{3}\right)$, tidak berpengaruh positif dan signifikan terhadap Kinerja Pegawai di Bank Danamon Syariah Makassar.

Hipotesis yang telah diajukan "Quality Of Work Life yang terdiri dari variabel Sistem Imbalan, Lingkungan kerja, Restrukturisasi Kerja tidak semua berpengaruh positif terhadap Kinerja Pegawai di Bank Danamon Syariah Makassar". Berdasarkan hipotesis $\mathrm{H}_{1}$ tersebut maka dalam hal penelitian ini tidak sesuai dengan yang diajukan bahwa hipotesis tersebut terbukti.

\section{Pembahasan Variabel Quality Of Work Life yang Dominan Berpengaruh Secara Simultan Terhadap Kinerja Pegawai}

Persepsi Variabel $\mathrm{X}_{1}$ Sistem Imbalan berpengaruh dominan secara simultan terhadap Kinerja Pegawai di Bank Danamon Syariah Makassar

Hasil pengujian secara parsial atau uji-T menunjukkan bahwa variabel Sistem Imbalan berpengaruh positif dan signifikan terhadap Kinerja Pegawai. Hal ini mengidentifikas adanya hubungan searah antara Sistem Imbalan dengan Kinerja Pegawai. Artinya pelayanan yang diberikan kepada pegawai berpengaruh terhadap kerja pegawai. Melihat pada pengertian Sistem Imbalan sendiri yang terdiri dari tunjangan, gaji, bonus pada dasarnya searah dengan Kinerja pegawai, dalam hal ini Sistem Imbalan menjadi acuan atau faktor yang paling dominan berpengaruh secara simultan terhadap minat Kinerja Pegawai.

Hasil pengujian ini menunjukkan bahwa variabel Sistem Imbalan berpengaruh positif dan signifikan terhadap kinerja pegawai. Dibuktikan dengan nilai t hitung sebesar 3,450 dan (sig) $=0,002$ lebih kecil dari probability yakni 0,05 atau $0,002<0,05$. 
Persepsi Variabel $\mathrm{X}_{2}$ Lingkungan Kerja Tidak Berpengaruh tehadap Kinerja Pegawai di Bank Danamon Syariah Makassar.

Hasil pengujian secara parsial atau uji-T menunjukkan bahwa variabel Lingkungan Kerja berpengaruh positif dan tidak signifikan terhadap Kinerja Pegawai. Hal ini mengidentifikasi tidak ada hubungan searah antara Lingkungan Kerja dengan Kinerja Pegawai. Artinya lingkungan kerja yang berupa lingkuang fisik, penetapan jam kerja dan aturan yang berlaku tidak menjadi faktor yang paling dominan terhadap kinerja pegawai.

Hasil pengujian secara parsial ini menunjukkan bahwa variabel Lingkungan Kerja berpengaruh negatif dan tidak signifikan terhadap Kinerja Pegawai. Dibuktikan dengan nilai t hitung sebesar 0,650 dan $($ sig $)=0,521$ lebih besar dari probability yakni 0,05 atau 0,521 >0,05.

Persepsi Variabel Restrukturisasi Kerja berpengaruh terhadap Kinerja Pegawai di Bank Danamon Syariah Makassar.

Hasil pengujian secara parsial atau uji-T menunjukkan bahwa variabel Restrukturisasi Kerja berpengaruh negatif dan tidak signifikan terhadap Kinerja Pegawai. Hal ini mengidentifikasi tidak adanya hubungan searah antara Restrukturisasi Kerja dengan Kinerja Pegawai. Perusahaan memberikan peluang karir dan mendorong pegawai berkembang lebih jauh dalam pekerjaan tidak menjadi faktor yang dominan terhadap kinerja pegawai.

Hasil pengujian secara parsial ini menunjukkan bahwa variabel Restrukturisasi Kerja berpengaruh negatif dan tidak signifikan terhadap Kinerja Pegawai Dibuktikan dengan nilai t hitung sebesar 0,239 dan $($ sig $)=0,813$ lebih besar dari probability yakni 0,05 atau $0,813>0,05$.

Artinya variabel sistem imbalan (X1) yang berpengaruh signifikan terhadap Kinerja Pegawai. Dengan demikian, hipotesis yang diajukan dalam penelitian ini sesuai dengan hasil penelitian

\section{Kesimpulan}

1. Berdasarkan hasil perhitungan secara parsial, pada variabel X1 yakni Sistem Imbalan sebesar 0,488 berpengaruh positif terhadap variabel Y yakni minat Kinerja Pegawai, artinya sistem imbalan menjadi acuan setiap pegawai Bank Danamon Syariah Makassar dalam kinerja pegawai. Selanjutnya pada variabel X2 yakni Lingkungan Kerja sebesar 0,081 tidak berpengaruh terhadap variabel Y yakni Kinerja Pegawai, dan pada variabel X3 yakni Restrukturisasi Kerja sebesar 0,033 tidak berpengaruh positif terhadap variabel Y yakni Kinerja Pegawai, jadi lingkungan kerja dan restrukturisasi kerja bukanlah hal yang mempengaruhi kinerja para pegawai Bank Danamon Syariah Makassar. Sehingga hipotesis yang diajukan sebagai hipotesis pertama (H1) yang menyatakan "Quality Of Work Life (QWL) Marketing yang terdiri dari variabel Sistem Imbalan, Lingkungan Kerja, dan Restrukturisasi Kerja tidak semuanya berpengaruh positif terhadap Kinerja Pegawai di Bank Danamon Syariah Makassar” terbukti. Hal ini membuktikan bahwasanya penerapan Quality Of work Life yang terdiri dari variabel tersebut pada Bank Danamon Syariah Makassar hanya sebagian yang dapat menciptakan dan meningkatkan Kinerja Pegawai pada perusahaan tersebut yakni variabel sistem imbalan.

2. Berdasarkan nilai signifikan pada uji T untuk variabel X1 Sistem Imbalan dengan nilai t hitung sebesar 3,450 dan nilai signifikan $=0,002$ lebih besar dari nilai probability yakni 0,05 atau 0,002 $<0,05$ artinya variabel Sistem Imbalan dominan berpengaruh terhadap Kinerja Pegawai. Untuk variabel X2 Lingkungan Kerja dengan nilai t hitung sebesar 0,650 dan nilai tidak siginifikan sebesar 0,521 lebih besar dari nilai probability yakni 0,05 atau $0,521>0,05$ artinya variabel Lingkungan Kerja tidak dominan berpengaruh terhadap Kinerja Pegawai. Variabel X3 Restrukturisasi Kerja dengan nilai t hitung sebesar 0,239 dan nilai tidak signifikan sebesar 0,813 lebih besar dari nilai probability yakni 0,05 


\section{Syarif Al Qadri, Moh. Yasin Soumena}

atau 0,813 > 0,05 artinya variabel Restrukturisasi tidak dominan berpengaruh terhadap Kinerja Pegawai. Dari hasil penelitian ini variabel yang paling berpengaruh dominan secara simultan adalah variabel Sistem Imbalan yang sangat berpengaruh terhadap Kinerja Pegawai 


\section{Daftar Pustaka}

Al-Qur'an dan Terjamahan. Kementerian Agama RI.

Aljuhri, M. (2012). Pengaruh Kualitas Kehidupan Kerja Dan Lingkungan Kerja Sekolah Terhadap Motivasi Berprestasi. Jurnal Administrasi Pendidikan, 14(1).

Anonim. (2017). BANK DALAM PENGAW ASAN KHUSUS (SPECIAL SURVEILLANCE). Https://Www.Ojk.Go.Id/Id/Kanal/Perbankan/Pages/Bank-Dalam-Pengawasan-Khusus.Aspx.

Badu Ahmad. (2008). KONDISI BIROKRASI DI INDONESIA DALAM HUBUNGANNYA DENGAN PELAYANAN PUBLIK. Jumal Administrasi Publik, 4.

Fadilla Helmi, A., \& Elita, Y. (2013). Efikasi Diri, Sistem Imbalan, dan Berbagi Pengetahuan: Meta-analisis. Buletin Psikologi, 21(1).

Finthariasari, M., Ekowati, S., Ranidiah, F., Yuniarti, R., \& Muchlis, M. (2020). PENGARUH WORKFAMILY CONFLICT TERHADAP TURNOVER INTENTION MELALUI KOMITMEN ORGANISASI. EKUITAS (Jumal Ekonomi Dan Keuangan), 4(3). https://doi.org/10.24034/j25485024.y2020.v4.i3.4584

Irawan, F., \& Ekapradana, I. G. A. P. (2020). Analisis Valuasi Nilai Pasar Wajar Saham Pt Bank Danamon Indonesia. Jurnal Pajak Indonesia, 4(2).

Lasmawati, I. I. (2020). Pengaruh Efektivitas Restrukturisasi Organisasi dan Dukungan Organisasi terhadap Komitmen Organisasional serta Dampaknya pada Kinerja Proses Bisnis Internal Perusahaan. Undpad Repository.

Manajemen, M. (2019). Jurnal Manajemen Bisnis Dan Kewirausahaan. Jurnal Manajemen Bisnis Dan Kewirausahaan, 2(3). https://doi.org/10.24912/jmbk.v2i3.4838

Mega Yunika, R. M. (2017). Pengaruh Restrukturisasi Organisasi Dan Pengawasan Kerja Terhadap Kinerja Karyawan Dengan Kepuasan Kerja Sebagai Variabel Intervening. Jurnal Manajemen, 5(2).

Muhammad Idris. D.M. (2018). PERANAN ORGANISASI TERHADAP PRILAKU INDIVIDU, DISIPLIN DAN MOTIVASI YANG BERDAMPAK MEMBANGUN KINERJA. Jurnal Ilmiah Akuntansi Dan Finansial Indonesia, 1(2). https://doi.org/10.31629/jiafi.v1i2.1246

Murtiyani, S. (2016). Restrukturisasi Sistem Dan Optimalisasi Program Pemberdayaan Masyarakat Miskin pada Sektor Mikro. Jurnal Ekonomi Islam, 14(1).

Paramarta, V. (2019). PENGARUH DISIPLIN TERHADAP KINERJA KARYAWAN PADA PT. BANK DANAMON, TBK. CABANG BANDUNG. Jumal Ekonomi Efektif, 1(4). https://doi.org/10.32493/jee.v1i4.10709

Putri, A. R. (2015). Analisis Kinerja Keuangan Pada Bank Umum Konvensional Dan Bank Umum Syariah Di Indonesia. In Jurnal Ekonomi Syariah (Vol. 3, Issue 1).

Rahayu, Y. (2018). PENGUKURAN HAK INVESTOR DARI HASIL KINERJA. EKUITAS (Jurnal Ekonomi Dan Keuangan), 7(4). https://doi.org/10.24034/j25485024.y2003.v7.i4.368 


\section{Syarif Al Qadri, Moh. Yasin Soumena}

Rizki, M., Parashakti, R. D., \& Saragih, L. (2019). The effect of transformational leadership and organizational culture towards employees' innovative behaviour and performance. International Journal of Economics and Business Administration, 7(1). https://doi.org/10.35808/ijeba/208

Rokhayati, I., Cahyo, H., \& Mulwati, E. (2020). Analisis Rasio Ineternal Perusahaan Yang Berpengaruh Terhadap Profitabilitas Pada Perusahaan Sub Sektor Perbankan Konvensional. Jurnal MONEX, 9(2).

Saputro, A. (2019). BUSINESS ETHIC \& GOOG CORPORATE GOVERNANCE (GCG) PADA PT BANK DANAMON INDONESIA Tbk. Jurnal Ekonomi Manajemen Sistem Informasi, 1(2). https://doi.org/10.31933/jemsi.v1i2.63

Setiawan, A. (2021). Analisis Yuridis terhadap Penataan Struktur Organisasi Kementerian dalam Rangka Peningkatan Reformasi Birokrasi. Supremasi Hukum: Jurnal Kajian Ilmu Hukum, 10(2). https://doi.org/10.14421/sh.v10i2.2313

Soepomo, P. (2013). Model Sistem Pendukung Keputusan Penilaian Kelayakan Pemberian Kredit. JSTIE (Jurnal Sarjana Teknik Informatika) (E-Journal), 1(1).

Suharyanto, Nugrahanto, B., \& Rum, A. I. (2012). Sistem Upah Berbasis Kinerja , Merangsang Karyawan Lebih Giat Bekerja? Tedc, 6(2).

Trimaya, A. (2014). Pemberlakuan Upah Minimum dalam Sistem Pengupahan Nasional untuk Meningkatkan Kesejahteraan Tenaga Kerja. Aspirasi: Jurnal Masalah-Masalab Sosial, 5(1).

Warpindyastuti, L. D. (2020). Nilai Bisnis Implementasi Sistem Informasi Perbankan ICBS (Integrated Computerized Banking System) Pada Bank Danamon Indonesia Tbk. JABE (Journal of Applied Business and Economic), 6(3). https://doi.org/10.30998/jabe.v6i3.3520 